\title{
Synthesis of Zeolite A employing Amazon kaolin waste
}

\section{(Síntese de Zeólita A empregando resíduo de caulim amazônico)}

\author{
S. H. da Silva Filho', L. Bieseki ${ }^{1}$, A. R. da Silva ${ }^{1}$, A. A. B. Maia ${ }^{2}$, R. A. S. San Gil ${ }^{3}$, S. B. C. Pergher \\ ${ }^{1}$ Laboratório de Peneiras Moleculares - LABPEMOL, Instituto de Química, UFRN, \\ Av. Senador Salgado Filho 3000, Lagoa Nova, Natal, RN 59078-900 \\ ${ }^{2}$ Centro de Ciências Exatas e Tecnologia, Universidade da Amazônia- Unama, Av. Alcindo Cacela 28, \\ Belém, PA 66060-902 \\ ${ }^{3}$ Instituto de Química, Lab. RMN de Sólidos, Universidade Federal do Rio de Janeiro, Ilha do Fundão, \\ Rio de Janeiro, RJ 21941-900
}

\begin{abstract}
The synthesis of zeolite A employing kaolin waste from paper coating was studied. The kaolin waste was pre-treated at 550 to $800^{\circ} \mathrm{C}$. For comparison purposes, a sample of zeolite A was also prepared using the IZA procedure. The materials were characterized by $27 \mathrm{Al}$ MAS NMR, X-ray diffraction and scanning electron microscopy using a microprobe. Pretreatment was necessary, and the best temperatures were between 600 and $700{ }^{\circ} \mathrm{C}$. The zeolite A formation was observed in all the prepared materials, reaching $52 \%$ crystallinity. On the other hand, the sodalite phase and amorphous materials were also formed.
\end{abstract}

Keywords: kaolin waste, zeolite synthesis, zeolite A.

\section{Resumo}

Estudou-se a síntese de zeólita A empregando resíduo de caulim de recobrimento de papel. O resíduo de caulim foi pré-tratado a $550{ }^{\circ} \mathrm{C}$ para $800^{\circ} \mathrm{C}$. Para fins de comparação, uma amostra de zeólita A foi também preparada utilizando o procedimento IZA. Os materiais obtidos foram caracterizados por $27 \mathrm{Al}$ MAS NMR, difração de raios X e microscopia eletrônica de varredura usando uma microssonda. O pré-tratamento foi necessário, e as melhores temperaturas foram entre 600 e $700{ }^{\circ} \mathrm{C}$. A formação de zeólita A, foi observada em todos os materiais preparados, atingindo $52 \%$ de cristalinidade. Por outro lado, a fase sodalita e materiais amorfos também foram formados.

Palavras-chave: resíduo de caulim, a sintese de zeólitas, zeólita A.

\section{INTRODUCTION}

Although there have been many studies related to the synthesis of zeolite Afrom kaolin [1-4], it is important to consider the different characteristics of this clay mineral when derived from different regions, which can directly influence the yield of the final synthesis product. In Brazil, the kaolin reserves are almost entirely concentrated $(93 \%)$ in the sedimentary deposits of the three largest kaolin districts in the country: Rio Capimin the State of Para,Jaríin the State of Amapáand a third deposit in the State of Amazon.

Kaolin presents a layered structure, composed of sheets of Si tetrahedral and $\mathrm{Al}$ octahedral with common oxygen, with the formation of a 1:1 layer [5] (Fig. 1A). As kaolins present an $\mathrm{Si} / \mathrm{Al}$ ratio of approximately 1.0, their composition is suitable for zeolite Asynthesis (Fig. 1B), which also has an $\mathrm{Si} / \mathrm{Al}$ ratio of approximately 1.0 .

The objective of this work is to study the zeolite Asynthesis employing kaolin generated as waste in the process of paper production in the Amazon region as a source of Si and Al. As described [4], industrial waste kaolin is actually kaolin itself, but with granulometric sizes larger

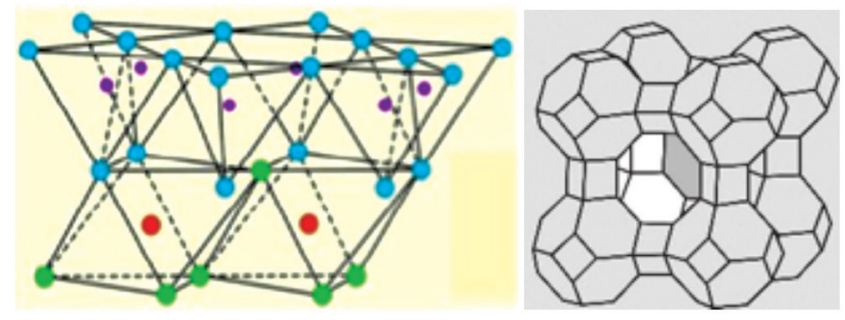

Figure 1: Kaolin structure (A) and zeoliteA(B). Adapted from [6, 7]. [Figura 1: Estrutura do caulim (A) e zeolita A (B) adaptado [6, 7].]

than required for the purposes of the hedging paper process. For this reason, it is considered waste. The zeolite A is often used in industries as an ion exchanger and a molecular sieve, in addition to being an efficient water softening agent in detergent formulation [8].

\section{EXPERIMENTAL}

Zeolite synthesis

For comparison and to evaluatethe crystallinity of the 
synthesized samples, a standard synthesis of zeolite A was performed according to the IZA procedure (International Zeolite Association) [9]. The steps of this synthesis are described in Table I.

Table I - Order of reagents used in zeolite A synthesis, IZA standard procedure.

[Tabela I - Ordem dos reagentes utilizados na sintese da zeolita A, procedimento padrão IZA.]

\begin{tabular}{cl}
\hline Steps & \multicolumn{1}{c}{ Procedure } \\
\hline 1 & $40 \mathrm{~g}$ distilled $\mathrm{H}_{2} \mathrm{O}+0.4 \mathrm{~g} \mathrm{NaOH}$ \\
2 & Divide into two parts, $\mathrm{V} 1$ and $\mathrm{V} 2$ \\
3 & $\mathrm{~V} 1+4.1$ g sodium aluminate \\
4 & Stir until dissolved \\
5 & $\mathrm{~V} 2+2.2 \mathrm{~g}$ silica $+2.9 \mathrm{~g} \mathrm{NaOH}+3.3 \mathrm{~g} \mathrm{H}_{2} \mathrm{O}$ \\
6 & Pour V1 into V2, stirring for $30 \mathrm{~min}$ \\
7 & Crystallized samples in autoclave for $4 \mathrm{~h}$ at $100{ }^{\circ} \mathrm{C}$ \\
\hline
\end{tabular}

As an alternative source of silicon and aluminum for zeolite Asynthesis, calcined kaolin samples were used at $550,600,700$ and $800{ }^{\circ} \mathrm{C}$. The synthesis of these different materials was performed according to the following procedure. In the first stage, $0.881 \mathrm{~g} \mathrm{NaOH}$ is dissolved in $11.621 \mathrm{~g}$ of $\mathrm{H}_{2} \mathrm{O}$, and to this solution $0.037 \mathrm{~g}$ of sodium aluminateis added. After dissolving these reagents, $8.478 \mathrm{~g}$ ofmetakaolin is added. The samples are placed in an autoclave and then inan oven at $115^{\circ} \mathrm{C}$.

\section{Characterization of the starting and synthesized materials}

${ }^{27} \mathrm{AlRMN}-\mathrm{MAS}$ analyses were performed for the natural kaolin samples calcined at different temperatures in a Bruker Advance III $400(9.4 \mathrm{~T})$ at $104.3 \mathrm{MHz}\left({ }^{27} \mathrm{Al}\right)$, with a probe of $3.2 \mathrm{~mm}$ and a rotational speed of $12 \mathrm{kHz}$.

To determine the zeolitic phases, the synthesized samples were characterized by X-ray diffraction in a diffractometer Siemens D5000, with a Ni filter and Cuka radiation $(\lambda=1.54 \AA)$.

Scanning electron microscopy and chemical analysis were performed on the same samplesin a microprobe EPMA Shimadzu $1720 \mathrm{H}$, with an accelerating voltage of $15 \mathrm{kV}$ and $\mathrm{BC}$ ranging from $50 \mathrm{nA}$ to $0.01 \mathrm{nA}$. The samples were prepared by dispersion in a carbon ribbon and gold plating.

\section{RESULTS AND DISCUSSION}

\section{Characterization of metakaolin coverages amples}

In the ${ }^{27} \mathrm{Al}$ RMN-MAS of the untreated kaolin sample, an intense signal is observed at approximately $0 \mathrm{ppm}$ due to the presence of octahedral $\mathrm{Al}[10,11]$.This result is consistent with the kaolin samples, which consist of an aluminum octahedral sheet without isomorphous substitution in the tetrahedral sheet.

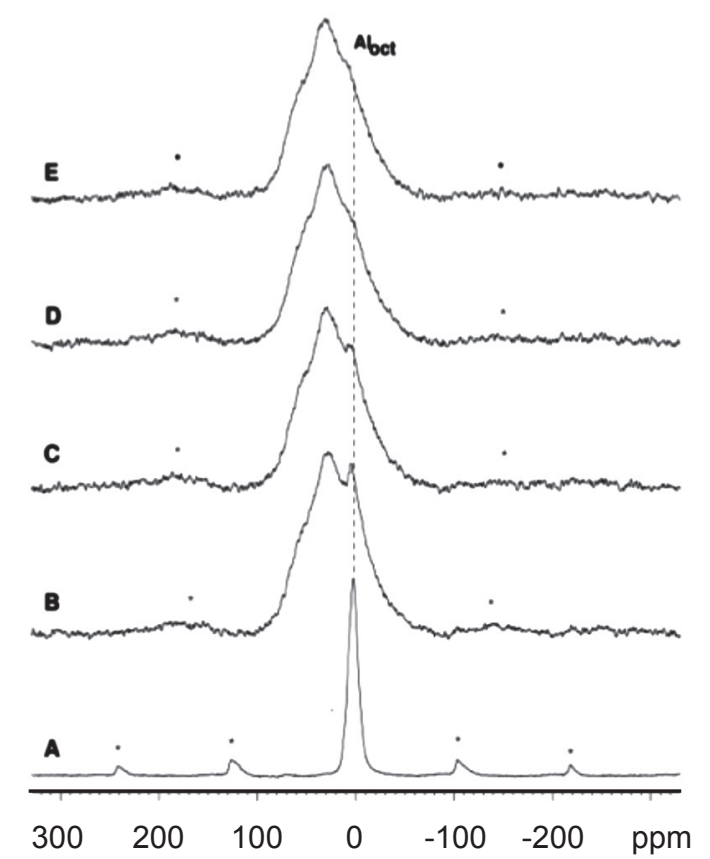

Figure 2: ${ }^{27} \mathrm{AlRMN}-\mathrm{MAS}$ spectra of kaolin precursor samples (A) and after calcination at 550 (B), 600 (C), 700 (D) and $800{ }^{\circ} \mathrm{C}$ (E).*Rotational bands.

[Figura 2: Espectros de RMN-MAS de ${ }^{27}$ Al de amostras precursoras de caulim (A) e após calcinação a 550 (B), $600(C), 700(D)$ e $800{ }^{\circ} \mathrm{C}$ (E) * bandas de rotação.]

Fig. 2 shows the ${ }^{27} \mathrm{Al}$ RMN-MAS spectra of the ${ }^{27} \mathrm{Al}$ in the calcined kaolin coverage samples calcinedat different temperatures. The calcined samples exhibitan extremely extended Al signal, and there is a slight decrease in the content of octahedral $\mathrm{Al}$ as the temperature increases from $550{ }^{\circ} \mathrm{C}$ to $800{ }^{\circ} \mathrm{C}$, according toreported results $[4$, 10-13]. Although the position of the maximum signal was observed in the region between tetrahedral and octahedral $\mathrm{Al}$, it might represent tetrahedral $\mathrm{Al}$ with large asymmetry, or substitutions affecting the tetrahedral angles, rather thanpentahedral sites.

\section{Zeolite synthesis}

Fig. 3 shows the diffraction patterns of the sample synthesized under standard conditions, according to the IZA synthesis. The observed reflections are consistent with the LTA structure of zeolite A, showing through their intensities a crystal clear material. The figure insert shows the micrograph for this sample, which reveals the typical morphology of zeoliteA, cubes.

The synthesis using kaolin waste without heat treatment (calcination) did not produce any zeolite phase; the material obtained was completely amorphous.

Fig. 4 shows the diffraction patterns of the synthesized zeolites using samples of kaolin waste calcined at different temperatures. These samples show the characteristic properties of zeolite A. Comparing these diffraction patterns with the one of the standard zeolite A, it was observed that 

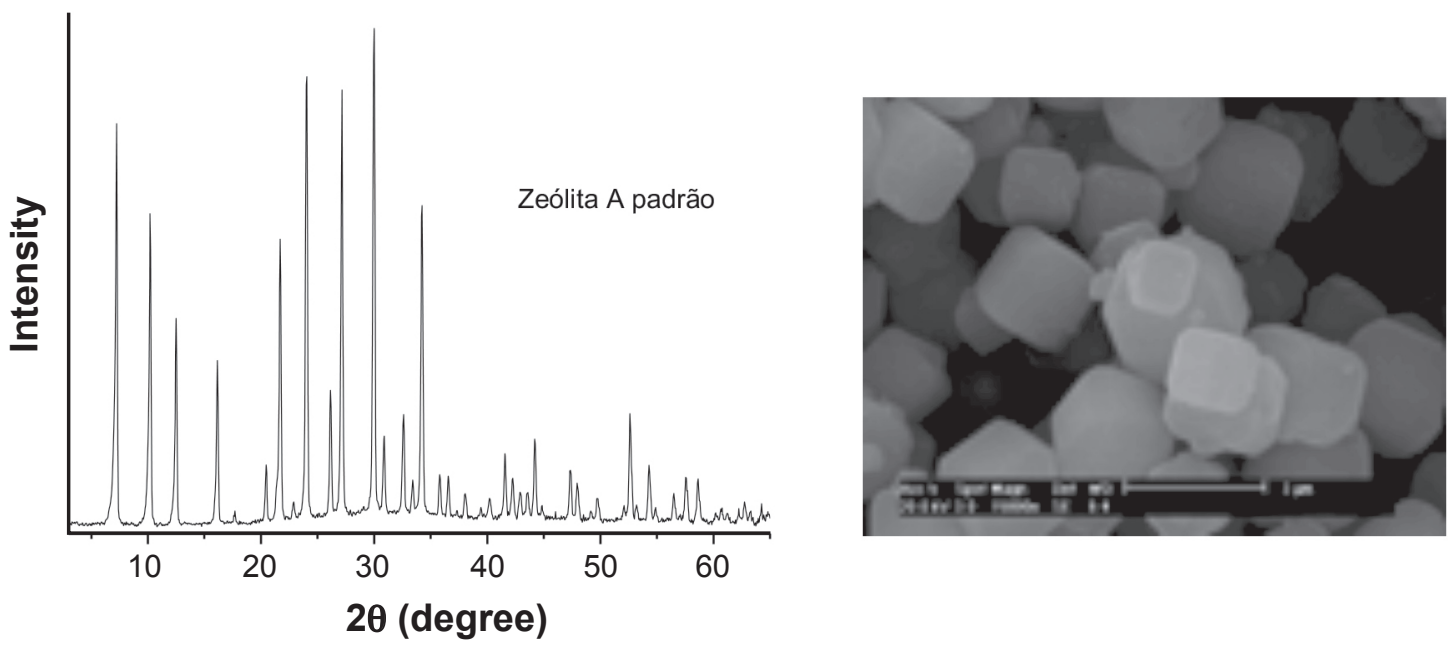

Figure 3: X-ray diffraction pattern of zeolite A- standard synthesis IZA.

[Figura 3: Difratograma de raios $X$ da zeolita $A$ - sintese padrão IZA.]

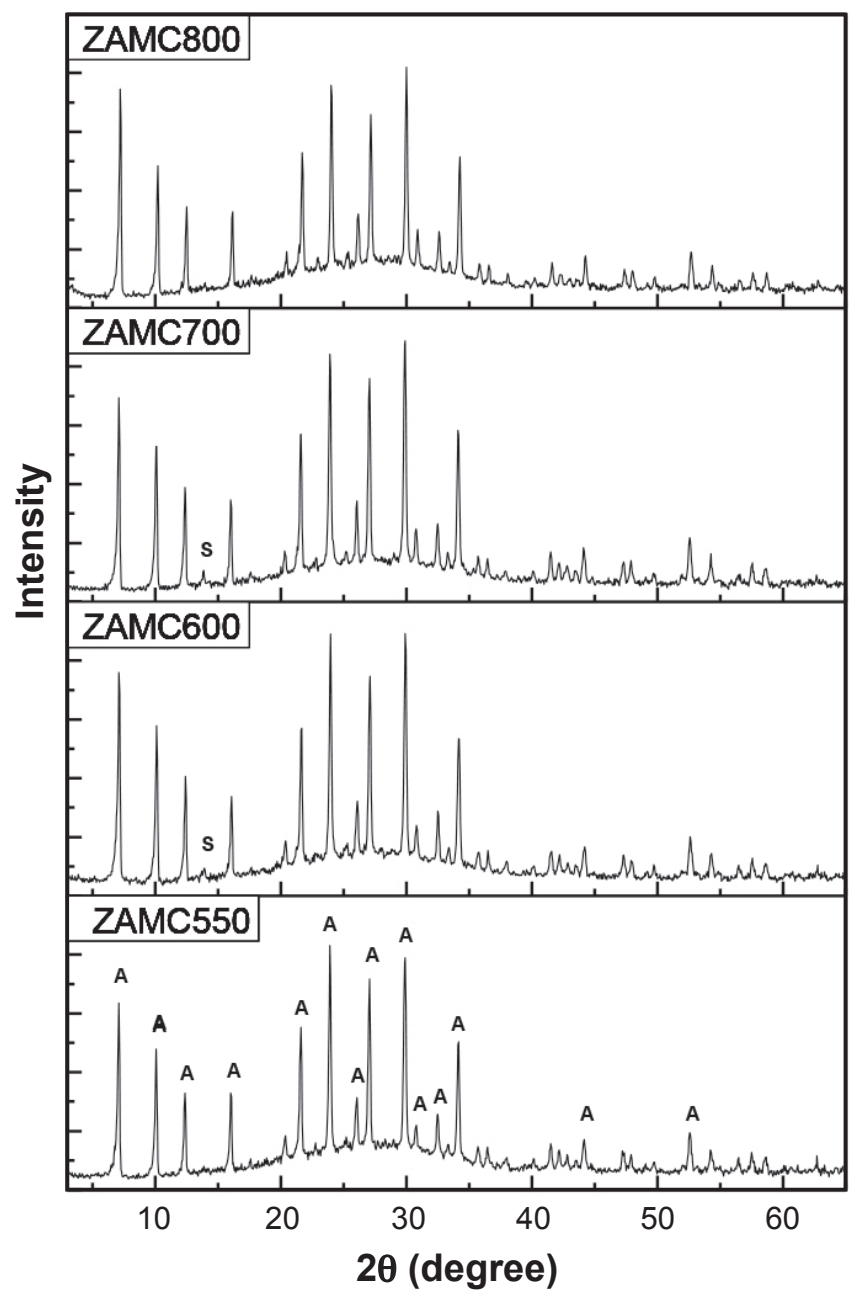

Figure 4: X-ray diffraction patterns of samples synthesized using calcined kaolin at different temperatures. A -zeolite A and S sodalite.

[Figura 4: Difratogramas de raios $X$ das amostras sintetizadas com caulim calcinadas em diferentes temperaturas. $A$ - zeolita $A$ e $S$ - sodalita.]
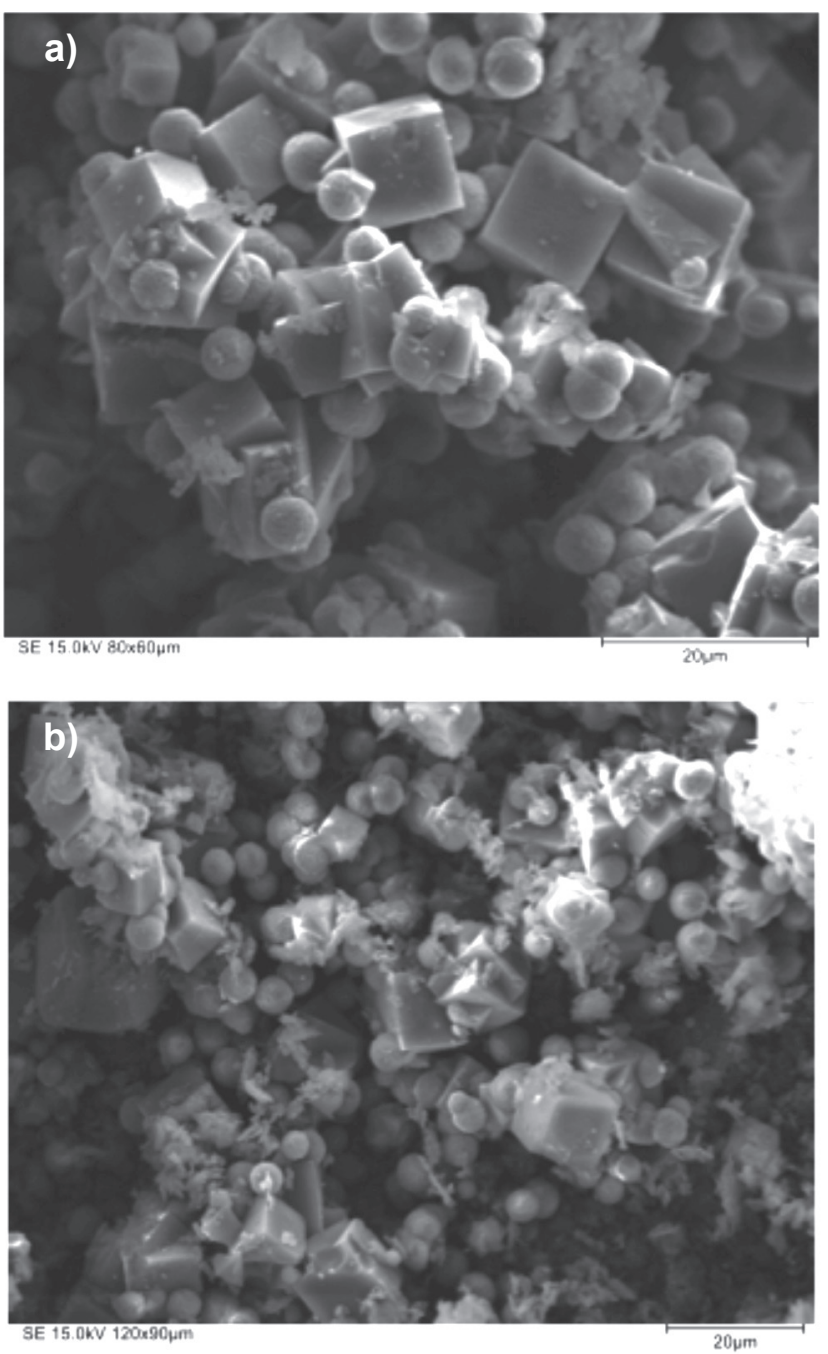

Figure 5: SEM micrographs of the sample synthesized using kaolin calcined at $600{ }^{\circ} \mathrm{C}$ - ZAMC600.

[Figura 5: Micrografias obtidas em microscópio eletrônico de varredura das amostras sintetizadas usando caulim, calcinadas a $600{ }^{\circ} \mathrm{C}-$ ZAMC600.] 
Table II - Chemical analysis of the material, obtained with a microprobe.

[Tabela II - Analise química do material, obtida com microssonda.]

\begin{tabular}{cccccc}
\hline Sample & $\begin{array}{c}\% \mathrm{Si} \\
(\mathrm{p} / \mathrm{p})\end{array}$ & $\begin{array}{c}\% \mathrm{Al} \\
(\mathrm{p} / \mathrm{p})\end{array}$ & $\begin{array}{c}\% \mathrm{Na} \\
(\mathrm{p} / \mathrm{p})\end{array}$ & $\begin{array}{c}\mathrm{Na} / \mathrm{Al} \\
(\mathrm{molar})\end{array}$ & $\begin{array}{c}\mathrm{Si} / \mathrm{Al} \\
(\mathrm{molar})\end{array}$ \\
\hline ZAMC550 & 24.30 & 7.60 & 16.70 & 2.58 & 3.07 \\
ZAMC600 & 24.20 & 7.70 & 15.97 & 2.43 & 3.02 \\
ZAMC700 & 16.92 & 5.39 & 25.51 & 5.55 & 3.01 \\
ZAMC800 & 18.05 & 3.60 & 28.04 & 9.14 & 4.81 \\
\hline
\end{tabular}

in the $2 \theta$ range of 20 to $35^{\circ}$ the increase in background indicates the presence of amorphous material. The samples presented less intense reflections than the standard sample. The relative crystallinity of the synthesized samples was calculated using Equation A. The peak areas at $2 \theta$ values of $7.2^{\circ}, 12.5^{\circ}, 16.1^{\circ}, 21.7^{\circ}, 30^{\circ}$, and $34.2^{\circ}$ were used to evaluate the crystallinity.

The relative crystallinity found for the products of synthesis using the calcined samples at 550, 600, 700 and $800{ }^{\circ} \mathrm{C}$ are $47,52,52$ and $45 \%$, respectively.

The micrographs of the zeolitic materials obtained using the calcined kaolin at different temperatures (Fig. 5) were similarand are represented by Fig. 5A, which shows the micrograph of the sample obtained from kaolin calcined at $600{ }^{\circ} \mathrm{C}$. Cubic morphology is observed, which is typical of the LTA structure (zeolite A), with the intergrowth of crystals. Spherical crystals (clusters) characteristic of the sodalite phase (SOD), which competes in the synthesis of zeolite A, are also observed and can be identified by the appearance of a small reflection in the diffraction pattern at $2 \theta 13.84^{\circ}$. These results have also been reported [4, 14-17]. Fig. 5B shows another micrograph of the same sample, in another region, which again shows the cube-shaped crystals (zeolite A), the spherical crystals (sodalite) and deformed crystals, indicating the presence of amorphous material, which is consistent with the X-ray diffraction results, as also shown previously $[9,16]$.In some micrographs, hexagonal cubic crystals are also observed, another morphology presented byzeolite A.

A semi-quantitative chemical analysis was performed using a probe, and the results are summarized in Table II.As the experiment was not a total analysis, it is noted that the molar ratio $\mathrm{Si} / \mathrm{Al}$ is larger than 1.0 . The increase in sodium with increasing calcining temperature, coinciding with the less crystalline materials, is noteworthy. Once the zeolite Astructure is formed, the molar ratio of $\mathrm{Si} / \mathrm{Al}$ must be equal to 1.0 , and the molar ratio $\mathrm{Na} / \mathrm{Al}$ also must be equal to 1.0 , as each $\mathrm{Na}$ atom would compensatefor the load of each $\mathrm{Al}$ tetrahedral.

\section{CONCLUSIONS}

The kaolin pre-treatment is required for the transformation of the metakaolin and subsequent zeolite A synthesis.
Through solid NMR analysis, the transformation of the octahedral Alto asymmetric tetrahedral Al was observed. Increased temperature leads to a decrease in octahedral aluminum, which indicates the necessity of calcining kaolin at temperatures from 600 to $700{ }^{\circ} \mathrm{C}$. The samples formed the desired structure, zeolite $\mathrm{A}$, but amorphous material and the sodalite phasewere also detected. This result suggests that the synthesis can still be optimized to achieve a higher zeolite Ayield.

\section{ACKNOWLEDGMENTS}

To CNPq for financial aid and to PPGQ.

\section{REFERENCES}

[1] J. Rocha, J. Klinowski, J.M. Adams, "Synthesis of zeolite NaA from metakaolinite revisited”, J. Chem. Soc., Faraday Trans. 87 (1991) 3091-3097.

[2] L. Heller-Kallai, I. Lapides, "Reactions of Kaolinites and Metakaolinites with $\mathrm{NaOH}$; comparison of different samples (Part 1)", Appl.Clay Sci. 35(2007) 99-107.

[3] R.T. Rigo, S.B.C. Pergher, "Um novo procedimento de síntese da zeólita A empregando argilas naturais", Química Nova 39, 1 (2009) 21-25.

[4] A.A.B. Maia, "Desenvolvimento do processo de síntese da zeólita a e da sodalita a partir de rejeitos de caulim da amazônia com aplicações em adsorção", M.Sc. Diss. Federal Univesity of Pará, Brazil (2011).

[5] R.E. Grim, Clay Mineralogy, McGraw- Hill, New York (1953) 384 pp.

[6] http://pubs.usgs.gov/of/2001/of01041/htmldocs/clays/ kaogr.htm

[7] A.J.S. Mascarenhas, E.C. Oliveira, H.O. Pastore, "Peneiras Moleculares: Selecionando as moléculas pelo seu tamanho", Cad.Tem. Quimica Nova na Escola (2001) 25-34.

[8] F.K. Sutili, N. Miotto, E. Rigoti, S.B.C. Pergher, F.G. Penha, "Aplicação de zeólitas sínteticas como coadjuvante em formulação detergente", Quimica Nova 32 (2009) 879883.

[9] www.iza-online.org/synthesis.

[10] J. Sanz, A. Madani, J.M. Serratosa, S. Aza, “Aluminum 27 and Silicon - 29 Magic - Angle Spinning Nuclear Magnetic Resonance. Study of the Kaolinite-MulliteTransformation", J. Am. Ceram. Soc. 71, 10 (1988) C418-C421.

[11] J. Rocha, J. Klinowski, "29Si and 27Al magicangle-spinning NMR studies of thermal transformation of Kaolinite", Phys. Chem. Mineral. 17 (1990) 179-186.

[12] D. Massiot, P. Dion, J.F. Alcover, F. Bergaya, "27Al and 29Si MAS NMR study of kaolinite thermal decomposition by controlled rate thermal analysis", J. Am. Ceram. Soc. 78 (1995) 2940-2944.

[13] H.P. He, J.G. Guo, J.X. Zhu, C. Hu, "29Si and 27Al MAS NMR study of the thermal transformations of kaolin from North China", Clay Minerals 38, 4 (2003) 551-559.

[14] A. Gualtieri, P. Norby, G. Artioli, J. Hanson, "Kinetics 
of formation of zeolite Na-A (LTA) from natural kaolinites", Phys. Chem. Mineral. 24, 3 (1997) 191-199.

[15] M. Alkan, C. Hopa, Z. Yilmaz, H. Guler, "The effect of alkali concentration and solid/liquid ratio on the hydrothermal synthesis of zeolite $\mathrm{NaA}$ from natural kaolinite", Microporous Mesoporous Mater. 86 (2005) 176184.
[16] A.A.B. Maia, E. Saldanha, R.S. Angélica, C.A.G. Souza, R. F. Neves, "The use of kaolin wastes from the Amazon region on the synthesis of Zeolite A", Cerâmica 53 (2007) 319-324.

[17] A.A.B. Maia, R.S. Angélica, R.F. Neves, "Use of industrial kaolin waste from the Brazilian Amazon region for synthesis of zeolite A, Clay Minerals 46 (2011) 127-136. (Rec. 17/01/2015, Rev. 21/05/2015, Ac. 02/07/2015) 